\title{
The Evolutionary Development of High Specific Impulse Electric Thruster Technology
}

James S. Sovey, John A. Hamley, Michael J. Patterson, and Vincent K. Rawlin

National Aeronautics and Space Administration

Lewis Research Center

Cleveland, Ohio

and

Roger M. Meyers

Sverdrup Technology, Inc.

Lewis Research Center Group

Brook Park, Ohio

Prepared for the

Space Programs and Technologies Conference

sponsored by the American Institute of Aeronautics and Astronautics Huntsville, Alabama, March 24-27, 1992

\section{NOSA}




\title{
THE EVOLUTIONARY DEVELOPMENT OF HIGH SPECIFIC IMPULSE ELECTRIC THRUSTER TECHNOLOGY
}

\author{
James S. Sovey, John A. Hamley, Michael J. Patterson, \\ and Vincent K. Rawl in \\ National Aeronautics and Space Administration \\ Lewis Research Center \\ Cleveland, Ohio 44135 \\ and \\ Roger M. Myers \\ Sverdrup Technology, Inc. \\ NASA Lewis Research Center Group \\ Brookpark, Ohio 44142
}

\section{ABSTRACT}

Electric propulsion flight and technology demonstrations conducted primarily by Europe, Japan, Peoples Republic of China, USA, and USSR are reviewed. Evolutionary mission applications for high specific impulse electric thruster systems are discussed, and the status of arcjet, ion, and magnetoplasmadynamic thruster and associated power processor technologies are summarized.

\section{INTRODUCTION}

Most spacecraft use low thrust chemical propulsion systems for either apogee topping, stationkeeping, attitude control, orbit transfer/control, and/or drag makeup. In many cases the use of high specific impulse electric propulsion can significantly reduce the required propellant mass, minimize low Earth orbit (LEO) propellant logistics for space platforms, extend mission life, and in some cases influence the choice of launch vehicles (refs. 1,2). Electric propulsion can positively impact mission performance, life, as well as initial and life-cycle cost.

During the last three decades more than 60 spacecraft using electric propulsion were deployed in Earth-orbit (refs. 3,4). While some electric propulsion (EP) systems were experimental, others provided drag makeup, attitude control, station-keeping, or orbit adjustments. The use of electric propulsion has been driven by the availability of spacecraft power and the state of space power system development. Nearly all electric thrusters developed to date for flight applications have power levels in the 3 to $2000 \mathrm{~W}$ range. The power levels available to propulsion are dictated by the spacecraft battery, fuel cell, or solar array capabilities. Solar arrays in the 2 to $3 \mathrm{~kW}$ range are now employed on geosynchronous satellites, and developinents in nickel-hydrogen batteries have provided an entree for low power electrothermal propulsion systems for NorthSouth stationkeeping (refs. 5-7). At present, the hydrazine resistojet and arcjet technologies have been transferred to industry for communication satellite 
applications. Larger solar arrays operating in the 5 to $12.5 \mathrm{~kW}$ range have reached a high level of technological maturity (ref. 8), and the SP-100 space nuclear power system, which could provide $100 \mathrm{~kW}$-class power levels, is currently being developed (ref. 9). There is also considerable interest in the maneuvering, orbit raising, and lunar transfer of small satellites, and fuel efficient electric propulsion systems may provide significant performance and mass benefits for these applications (refs. 1,10). New users of electric propulsion, in this evolutionary process, will likely be involved with Earth-space applications which might include technology demonstrations, orbit raising, apogee topping for comsats, and spacecraft maneuvering. Energetic solar electric propulsion (SEP) missions to planets, comets, and asteroids will receive strong attention from mission planners, and near-terin propulsion technologies will also focus on SP-100 nuclear electric propulsion (NEP) class mission applications (refs. 1, 8-11).

This paper will review electric propulsion flight and technology demonstrations conducted primarily by the USA. Some of the electric propulsion flight experiences of Europe, Japan, the Peoples Republic of China, and the Soviet Union are also discussed. Evolutionary mission applications for high specific impulse electric thruster systems will be presented, and the status of arcjet, ion, and magnetoplasmadynamic (MPD) thrusters and their associated power processor technologies will be summarized.

\title{
ELECTRIC PROPULSION FLIGHTS AND TECHNOLOGY DEMONSTRATIONS
}

\author{
Electric Propulsion Systems
}

The major flight qualified electric propulsion systems are resistojets, ion thrusters, ablative pulsed plasma thrusters, stationary plasma thrusters, pulsed magnetoplasmadynamic thrusters, and arcjets (refs. 12-32) (See Table I). At least 31 spacecraft have flown with resistojets used for North-South stationkeeping (NSSK), attitude control, orbit adjustment, or experiments. The Soviets report that about 60 stationary plasma thrusters (SPT) have been used on various satellites for periods up to 600 hours (ref. 4). Seven ion propulsion systems have been flown, one of which, the Space Electric Rocket Test (SERT-II), had ion thrusters that operated for periods in excess of 5 months (ref. 26).

Electrothermal Thrusters

Resistojets. - The most simple and lowest risk EP flight systems use nitrogen, ammonia, or hydrazine resistojets, which electrically auginent propellant heat exchangers to increase the specific impulse. The resistojets can be heated directly from the energy storage system or employ a single power supply at power levels that have ranged from 3 to about $500 \mathrm{~W}$ (ref. 31). From 1965 to 1971 over 20 spacecraft used nitrogen, ammonia, or hydrazine resistojets for stationkeeping, orbit maintenance, or experiments (ref. 31). In 1965 the VelaII spacecraft provided the first application of the resistojet (ref. 33) in which nitrogen thrusters were used for orbit adjustment. In 1968 the ATS-4 spacecraft successfully tested an $18 \mathrm{mN}$ ammonia resistojet system for a period of about $800 \mathrm{~h}$ (ref. 24). The most prevalent resistojet systems use hydrazine propellant storage and feed systems that have nearly the same technology as conventional monopropellant hydrazine systens (ref. 7). The "fuel efficient" 
hydrazine resistojets perform stationkeeping and have a specific impulse of $300 \mathrm{~s}$ versus $200 \mathrm{~s}$ for the conventional monopropellant hydrazine thrusters (ref. 5). At least 44 of the hydrazine resistojets or electrothermal hydrazine thrusters (EHT) have been developed by the Rocket Research Company and the General Electric Company for-communication satellite NSSK (ref. 7). TRW also developed EHT's that were flown aboard the INTELSAT-V series of spacecraft for NSSK (ref. 6).

Multipropeliant resistojets, using waste gases, have been baselined for the Space Station Freedom to provide drag makeup thus minimizing the need for propellant resupply and waste fluid return (ref. 34). The multipropellant resistojet has been successfully tested on $\mathrm{H}_{2}, \mathrm{He}, \mathrm{N}_{2}, \mathrm{CH}_{4}, \mathrm{Ar}, \mathrm{CO}_{2}$, and steam (ref. 35), and a $10,000 \mathrm{~h}$ lifetest was successfully performed using $\mathrm{CO}_{2}$ and $\mathrm{N}_{2}$ (ref. 36). Preliminary efforts have addressed propulsion system integration issues and the development of a zero-gravity steam generator (refs. 34,37).

Arcjets. - More recently, hydrazine arcjets have reliably demonstrated specific impulse levels up to $520 \mathrm{~s}$; such devices are now being flight qualified for AT\&T comsat NSSK (ref. 38). The hydrazine arcjets can provide a $50 \%$ to $100 \%$ increase in specific impulse over conventional chemical and resistojet thrusters. The increased "fuel efficiency" could save several hundred kilograms of propellant which could expand payload capability, extend satellite life, or reduce launch vehicle class (ref. 1). The hydrazine arcjet system has undergone thermal-mechanical qualification tests, cyclic-life tests, plume impact tests, as well as contamination and thermal loading experiments (refs. 1,38). Plume impacts on communications were addressed testing a FLTSATCOM qualification model spacecraft near the arcjet system (ref. 39). Antennas and probes, used to determine the extent of radiated and conducted electromagnetic emissions, revealed that radiated emissions from the arcjet and its power processor were within accepted limits at frequencies above $500 \mathrm{MHz}$, indicating conventional $\mathrm{GHz}$ class communications would not be affected by the kW-class arcjet system. The detailed assessment of arcjet/spacecraft integration issues is an ongoing program element within NASA and industry.

Nickel-hydrogen battery cycle-life and battery management technology for comsats has advanced significantly, and the under-utilized battery resource has provided acceptable risk for $\mathrm{kW}$-class resistojets and arcjets to perform satellite stationkeeping (refs. 7,40 ). Advanced batteries, hydrazine propellant management systems, and simple power processing schemes have been the foundation for the evolution from monopropellant hydrazine thrusters, to resistojets, to arcjet systems.

In anticipation of flights of higher power photovoltaic systems, the United States Air Force has sponsored the development of ammonia and hydrogen arcjets for orbit raising applications (ref. 32). Recently, a $30 \mathrm{~kW}$ ammonia thruster was developed and life tested by the Jet Propulsion Laboratory (JPL) for $573 \mathrm{~h}$. A thruster malfunction at $573 \mathrm{~h}$ was due to whisker growth on the tungsten cathode, and the anode constrictor experienced unacceptable erosion (ref. 41). Effects of power supply ripple on whisker growth, arcjet thermal design, and design verification tests are underway at lower power levels at JPL.

The Air Force, Aerospace Corporation, and TRW are in the process of defining the Electric Insertion Transfer Experiment (ELITE) which is a flight test of an 1800 $\mathrm{kg}$ spacecraft which uses ammonia arcjets for orbit transfer from $370 \mathrm{~km}$ to 3900 
$\mathrm{km}$ (ref. 42). Arcjet power level is in the $3 \mathrm{~kW}$ to $10 \mathrm{~kW}$ range, and thruster predevelopment work is underway at JPL (ref. 32). A $10 \mathrm{~kW}$ ammonia thruster was developed and life-tested for $1460 \mathrm{~h}$ (ref. 43). Thruster specific impulse was nominally $650 \mathrm{~s}$ at $36 \%$ overall efficiency. The test was terminated at $1460 \mathrm{~h}$ due to the fracture of a boron nitride insulator. Future work on the $10 \mathrm{~kW}$ ammonia thruster includes failure modes assessments, design modifications, and extended tests with cyclic and power throttling demonstrations.

The University of Stuttgart is conducting research on hydrogen thernal arcjets in the $30 \mathrm{~kW}$ to $100 \mathrm{~kW}$ range (ref. 44). Arcjet tests and analytical model development involve water-cooled thrusters so information can be obtained on anode power deposition and arc current distributions. This effort is an element of an SDIO/NASA research and technology program for solar electric orbit transfer vehicles (EOTV's) (ref. 1).

The NASA Lewis Research Center (LeRC) is also developing hydrogen arcjets in the $5 \mathrm{~kW}$ to $30 \mathrm{~kW}$ range for Earth-space applications (ref. 45). Laboratory-class radiation cooled arcjets are used to refine the design of devices scaled from $\mathrm{kW}-$ class arcjets, and to assess performance and life capability. Thrust efficiencies of $30 \%$ and $34 \%$ were obtained at $1460 \mathrm{~s}$ and $1040 \mathrm{~s}$ specific impulse, respectively. Testing was short-term, and extended tests are still required to establish the integrity of electrodes and long-term performance.

Ten kW-class arcjet propulsion will likely be flight tested on near-Earth precursors and operationally demonstrated on EOTV's that rely heavily on advances in photovolaic array technology. Flexible arrays using the Advanced Photovoltaic Solar Array (APSA) technology will probably achieve a specific power of $130 \mathrm{~W} / \mathrm{kg}$ for a wing size of $7.8 \mathrm{~kW}$. This may be an optimistic specific power since relatively thick cover-glass is required to minimize cell degradation during transit through the Van Allen belts (ref.8). Other solar array options include a flexible array (APSA) employing thin $f i l m$, radiation resitant cells and also concentrator arrays which provide more radiation protection and are "technology transparent" to the type of cells (refs. 8,46). The EOTV would certainly be a major step in the evolution of power, propulsion, and propellant management systems.

\section{Ion Thrusters}

A $10 \mathrm{~cm}$ diameter mercury electron bombardment ion thruster, first operated at NASA's LeRC in 1960, was developed, integrated into a propulsion system, and tested in 1964 on a ballistic flight in the Space Electric Rocket Test I (SERT I) (refs. 22,47). Electric propulsion flight information is summarized in Table I. The thruster test lasted 30 minutes and verified that the ion beam could be neutralized, and that the thrust produced was nearly equal to that expected from ground test measurements and calculations. Within a year, the Soviet Union was also conducting ion thruster tests in the upper atmosphere using argon, nitrogen, and air propellants under the YANTAR program (ref. 48).

Based on the success of SERT I, NASA developed a more powerful, long life, $15 \mathrm{~cm}$ diameter mercury ion thruster for a second $f l i g h t$ demonstration, designated SERT II (refs. 26,49-51). The SERT II system was launched into a sun-synchronous-1000 $\mathrm{km}$ high polar orbit in 1970. The extended operation of two SERT II thrusters demonstrated long term spacecraft and propulsion system compatibility in the geocentric environment (ref. 26). The two thrusters demonstrated operation for 
periods of 3880 and $2880 \mathrm{~h}$, respectively. Thruster restart was reliably accomplished after 11 years in space. The thrust level was confirmed by several methods, including altitude changes and on-board accelerometer measurements. The solar array for SERT II was the largest in space at that time and provided 1270 $W$ initially and about $800 \mathrm{~W}$ after more than 11 years in space. In 1981, the propellant supply was exhausted and thruster experimentation was terminated.

In 1974, the sixth Advanced Technology Satellite (ATS-6) was 1aunched into geosynchronous orbit (refs. 25;27). While the two electron bombardment cesium ion engines failed due to propellant feed system problems, neutralizer operation was satisfactory and demonstrated control of the spacecraft potential as the spacecraft went in and out of eclipse or experienced magnetic substorms.

Cooperation between Japan's National Space Development Agency (NASDA), the National Aerospace Laboratory (NAL), and the Electrotechnical Laboratory (ETL) resulted in a successful space flight test of a small (2. mN) mercury ion propulsion system on the third Engineering Test Satellite (ETS-III) in 1982 (refs. 52,53).

In addition to the experimental flights described above, several ion propulsion technology demonstration programs have been conducted in preparation for anticipated application. The success of NASA'S SERT II program led to the development of a propulsion system utilizing $8 \mathrm{~cm}$ diameter mercury ion thrusters sized for NSSK functions of small communications satellites in geosynchronous orbit. In the early 1980's, the Ion Auxiliary Propulsion System (IAPS) was integrated as an experiment on a proposed USAF spacecraft (refs. 54-56). Due to cancellation of the mission, the spacecraft is currently in storage.

In parallel with the IAPS program, NASA scaled the SERT II thruster upward in size and power to perform primary propulsion functions. LeRC initiated the Solar Electric Propulsion System (SEPS) technology program in the early. 1970 's. This program was directed toward the development of an electric propulsion stage for comet and asteroid rendevous mission applications (ref. 57). The $30 \mathrm{~cm}$ diameter $2.7 \mathrm{~kW}$ mercury ion thrusters, power processors, gimbals, thermal control systems, and propellant management systems were carried to an advanced state ofdevelopment. Thrusters and power processors demonstrated full mission capability by passing lifetime, thermal-vacuum, and vibration testing (ref. 58). Several extended tests of SEPS thrusters accumulated more than 30,000 h of operation over a wide range of conditions, in addition to another 30,000 $\mathrm{h}$ of day-to-day laboratory model thruster tests. Likewise, eight SEPS breadboard or higher level power processors accumulated more than $64,000 \mathrm{~h}$ of operation under various loads. In 1980, the SEPS technology was transferred to NASA's Marshall Space Flight Center.

Throughout the 1970's, mercury was the baseline propellant for ion thrusters because of its high molecular weight, low ionization potential, storability, and convenient vaporization. These features initially offset toxicity, reactivity, and facility/spacecraft contamination concerns. However, analyses conducted in the early 1980's indicated that inert gas propellants could provide some performance benefits, such as nearly instantaneous startup and significantly simplified power processing, which positively impact orbit raising and stationkeeping functions. Inert gases are also noncontaminating and simplify integration with the spacecraft and Earth-launch vehicles. They are also nontoxic and nonreactive when released to ground test facilities and/or the bio- 
sphere, minimizing ecological concerns. Because of these considerations, the inert gases xenon, krypton, and argon were tested in the baseline mercury thruster developed for the SEPS program at NASA's LeRC and JPL (refs. 59,60).

A xenon ion propulsion subsystem (XIPS) was developed by Hughes Research Laboratories (HRL) (with INTELSAT support) and ground tested (with NASA support) for $4350 \mathrm{~h}$ with 3850 on-off cycles (refs. 61,62). This test simulated over 10 years of stationkeeping for a large communications satellite. The XIPS thruster was $25 \mathrm{~cm}$ in diameter and produced about $64 \mathrm{mN}$ of thrust. HRL has also designed a propulsion system with similar technology using a $13 \mathrm{~cm}$ diameter thruster. This version produced about $18 \mathrm{mN}$ of thrust with an input power of $440 \mathrm{~W}$ (ref. 63). The thruster power supply contained only 400 parts, and the xenon tankage fraction was only $12 \%$ at a storage pressure of $7.6 \mathrm{MPa}$ (1100 psi). Preparations for long-term cyclic tests of qualification model thrusters are underway.

NASDA has also chosen to develop a xenon ion propulsion system for stationkeeping which utilizes $12 \mathrm{~cm}$ diameter, $23 \mathrm{mN}$ thrusters (refs. 21,64). Development of this Ion Engine System (IES) is a joint effort by NASDA, Mitsubishi Electric Corporation (MELCO), and Toshiba. The IES is slated to perform the NSSK functions for ETS-VI, which is scheduled for launch in the early 1990's (refs. $21,65)$. Likewise, the European Space Agency (ESA) has sponsored electric propulsion development resulting in xenon ion auxiliary propulsion systems (ref. 66). Germany's Radiofrequency Ion Thruster Assembly (RITA) is an experiment on the European Retrievable Carrier (EURECA-1) scheduled for launch in 1992 (refs. 67-69). RITA is also being developed as half of the NSSK propulsion system for the Advanced Relay and Technology Mission (ARTEMIS) planned for a 1995 launch. The United Kingdom's UK-10 ion thruster, which utilizes a conventional DC discharge to ionize propellant, rather than radio-frequency energy as in the RITA thruster, is being developed as the other propulsion system for ARTEMIS (ref. 70) (See Table I). Individual thrusters, for both the RITA and UK-10 systems, produce $10 \mathrm{~cm}$ diameter ion beams with thrust levels of 15 and $25 \mathrm{mN}$, respectively.

One focus of NASA's ion propulsion technology program is on near-term, near-Earth mission applications. Applications include auxiliary propulsion roles such as NSSK of geosynchronous spacecraft, as well as primary propulsion roles which include orbit transfer vehicle propulsion for the shuttling of large space structures and communications spacecraft from low to high Earth orbit. These mission applications are the primary drivers for the operational requirements and technology development needs for ion propulsion. Thruster power scaling technologies are also being addressed in support of the Space Exploration Initiative's Nuclear Propulsion Program which comprises both nuclear thermal and nuclear electric propulsion technologies. The nuclear electric propulsion (NEP) evolutionary path will probably involve robotic precursor flights using existing technologies such as the SP-100 program elements (ref. 9). Potential flight applications would involve missions to the moon, Pluto, or multiple asteroids (ref. 11). Later phases of an NEP program might involve development of cargo and piloted vehicles for missions to the moon and Mars (ref. 71).

To satisfy these mission requirements and achieve the goal of flight application of ion propulsion on operational spacecraft, developments have been focused toward obtaining user acceptance of the propulsion technology through system simplification, thereby effecting reduced development costs and reduced risk. These new directions include the transition from using mercury as the propellant 
to using the inert gases xenon, krypton, and argon. This change in propellants has brought simplification to design in the thruster, propellant management, and power processing, as well as in thruster operational requirements (throttling strategies, thruster starting, and re-starting).

During the 1980's a change in the plasma containment scheme was made from that used in the J-series thruster developed during the SEPS program. The current discharge chamber incorporates high field strength magnets to form a ring-cusp magnetic boundary. The design change was motivated by the need for a long-life $30 \mathrm{~cm}$ thruster optimized for operation with inert gas propellants, and the need for improved thruster performance at the lower specific impulse values associated with inert gas propellant operation. Other design modifications involved the technology of inert gas discharge and neutralizer hollow cathodes, as well as inert gas propellant management systems (ref. 72).

At NASA, the current programs are focused on the development of $30 \mathrm{~cm}$ xenon ion thruster technology for both auxiliary and primary propulsion applications in the 0.5 to $5 \mathrm{~kW}$ power range per thruster. Several mission studies have shown that significant mass savings can be realized by use of low power ion propulsion systems for auxiliary propulsion functions including NSSK and maneuvering of spacecraft (refs. 73-75). To optimize expectations for the implementation of ion propulsion systems for one or more of these applications, a low-risk "derated" approach is being pursued. In this derated approach, a $30 \mathrm{~cm}$ diameter xenon ion thruster, initially developed for primary propulsion, is operated at a fraction of its design and demonstrated power level (ref. 76). The derated xenon thrusters have provided specific impulse levels of $1700 \mathrm{~s}$ to $3000 \mathrm{~s}$ at overall efficiencies of $43 \%$ and $66 \%$, respectively. Ion thrusters being developed for NSSK under other programs are small compared to the $30 \mathrm{~cm}$ design and operate near both thermal and current density limits (ref. 76). The advantages of using this derated approach include elimination of known life limiting issues, increased thrust-to-power ratio, reduced flight qualification times, and provisions for a growth option to primary propulsion.

A recent study indicated that satellite mass in geosynchronous orbit decreased by approximately $17 \mathrm{kilograms}$ for each kilogram reduction in thruster mass (ref. 73). Because of this, a mass and volume reduction program has been initiated at NASA LeRC with the derated thruster. The mass of a $30 \mathrm{~cm}$ diameter laboratory thruster is $10.7 \mathrm{~kg}$ (ref. 77). Using novel approaches to the discharge chamber design and magnetic circuit, development of an engineering model thruster with a mass under $7 \mathrm{~kg}$ appears feasible.

In concert with the derated ion thruster development effort, joint testing programs are being established with NASA and industry to establish a broader US industrial base and awareness of ion thruster technology. NASA is providing engineering model $30 \mathrm{~cm}$ ion thrusters, and associated ground support equipment including power electronics and propellant feed systems, to conduct xenon ion thruster testing at industry sites.

Additionally, work is progressing on the development of larger ion thrusters for primary propulsion applications in the $10 \mathrm{~kW}$ to $20 \mathrm{~kW}$ input power range. Fifty centimeter diameter thrusters with dished ion optics have been developed. Xenon and argon efficiencies of about $70 \%$ have been obtained at specific impulse values of $4000 \mathrm{~s}$ and $7500 \mathrm{~s}$, respectively (ref. 78). Because of its low cost and good performance, krypton is a preferred propellant for higher power ion thrusters. 
The $10 \mathrm{~kW}$ to $20 \mathrm{~kW}$ ion thrusters may be used on systems employing SEP or SP-100 NEP class power systems for earth-space or planetary missions (refs. 11,42).

Plasma Thrusters

At least nine spacecraft have been flown using pulsed plasma thrusters whose propellant was ablative fluoropolymer products from solid Teflon propellant (See Table I.) These propulsion systems were either experiments, or provided drag makeup or stationkeeping. Average propulsion system power requirements were from 3 to $30 \mathrm{~W}$. Excluding resistojets, the NOVA-1 was the first USA spacecraft to use electric propulsion as an operational system without backup propulsion. The NOVA-1 pulsed plasina thrusters each produced $0.4 \mathrm{mN}-\mathrm{s}$ impulse bits from a main discharge of $1630 \mathrm{~V}$ (ref. 16). The system had a total impulse capability of about $2200 \mathrm{~N}-\mathrm{s}$ while requiring an average power of only $30 \mathrm{~W}$. As reported in 1989, three NOVA spacecraft were operational using pulsed plasma thrusters for drag makeup with a total of 14 spacecraft years of flight experience (ref. 17).

Two pulsed MPD arcjet experiments have been flown by Japan (refs. 19,20), and a third is scheduled in 1994 aboard the Space Flyer Unit-1 (SFU-1). The SFU-1 experiment will be the first space test to validate the propulsion performance of pulsed MPD thrusters (ref. 21). The pulsed MPD arcjet tested aboard Spacelab1 in 1983 produced a peak power of about 2 MW during a series of 1 ms pulses (ref. 20). This was the highest peak power plasma source ever flown on a spacecraft which in this case was the USA Shuttle Orbiter. The objectives of the Spacelab-1 experiment were associated with spacecraft charge control, airglow excitation, and plasmadynamic experimentation while the objectives of the 1994 SFU-1 experiment are related to spacecraft propulsion. The primary objective is to "verify the survivability of the MPD thruster system against launch and space environments" and to compare ground and space propulsion performance (ref. 21).

More than 50 Stationary Plasma Thrusters (SPT) have been used on Soviet spacecraft since 1972 on various series of satellites: Meteor, Gorizont, and Ekran (refs. 4,79). In the SPT a plasma is formed by a discharge from an external cathode to an anode channel with an external applied magnetic field. Ions are accelerated by an electric field in the channel, and the exhaust is volume neutralized by cathode electrons. Flight qualified SPT's have operated with xenon at nominal power levels up to $0.7 \mathrm{~kW}$ producing about $30 \mathrm{mN}$ of thrust at values of specific impulse from 1000 to $2000 \mathrm{~s}$ (ref. 79). In addition to providing orbit adjustment, the SPT's have also been used in investigations of the ionosphere on several satellite series (ref. 4). The SPT has been ground tested for periods of 3000 to $4000 \mathrm{~h}$, and operating time on orbit has exceeded $600 \mathrm{~h}$ (ref. 79).

The Soviets have also flown pulsed plasma thrusters on Zond-2 and the Ariel series of experiments. Butt-end Hall plasma thrusters have been flown aboard the Kosmos and Kust series of spacecraft in the 1975 to 1985 time period (ref. 4). Very little technical information concerning flights of the Soviet plasma thrusters is available in English translation.

Steady-state MPD thrusters producing over $5000 \mathrm{~s}$ specific impulse at over 30 percent efficiency have been demonstrated (refs. 80,81). While these devices have been studied for over 25 years, they have yet to demonstrate the combination of performance and lifetime required for orbit raising or planetary propulsion applications. However, the simplicity and robustness of their design makes them 
attractive for major NASA missions if these limitations can be overcome. As discussed in recent review papers (refs. 80,81), past efforts have focused principally on pulsed multimegawatt, self-induced magnetic field thrusters, or $30 \mathrm{~kW}$ to $100 \mathrm{~kW}$ steady-state applied-magnetic field thrusters. The apparent inability of the thrusters studied in those efforts to provide the performance and lifetime required has forced a renewed emphasis on MPD thruster technology at NASA. At present, efforts are underway to quantify the dominant performance loss mechanisins and establish their dependence on thruster geometry and operating conditions. At NASA LeRC, applied magnetic field MPD thrusters are cperated in test facilities permitting direct measurements of thruster performance.

A major effort to establish the dependence of MPD thruster efficiency and specific impulse on applied-field thruster geometry was recently completed at NASA LeRC (ref. 82). Both anode and cathode radii and lengths were varied by a factor of two using straight cylindrical thrusters, and a flared anode thruster was tested to obtain a preliminary assessment of the affect of electrode shape. Thruster performance as a function of applied magnetic field strength was obtained for a variety of propellant flow rates and discharge currents, and for both argon and hydrogen propellants. The highest performance obtained was 3700 s specific impulse at $20 \%$ efficiency using hydrogen propellant. Performance results for three anode radii were obtained. The thruster with the smaller radius anode provided highest efficiency; the impact of the applied-field increased dramatically for the larger thrusters. Results obtained for the thruster geometry matrix were used to establish empirical geometric scaling relationships valid for argon propellant at a discharge current of $1000 \mathrm{~A}$. The highest demonstrated thruster power was $220 \mathrm{~kW}$.

In addition to direct performance measurements, considerable effort has been placed on identifying and mitigating the dominant efficiency loss mechanisms. Calorimetric studies of electrode power deposition using both continuous (ref. 82) and segmented (ref. 83) anodes clearly show that between 50 and $80 \%$ of the power input to the thruster is lost to the anode. This fraction was found to decrease with both increasing anode radius and increasing applied magnetic field strength. Plasma property measurements, applied-field strengths, and anode power deposition show a striking correlation between the electron Hall parameter and the anode fall voltage, which may for the first time provide a physical basis for improved MPD thruster anode design (refs. 84,85). Plume property measurements at NASA LeRC and Ohio State University have shown that applied magnetic fields can strongly confine the exhaust plasma (ref. 86,87). These measurements also indicate that the applied-field can affect the cathode power balance by increasing the plasma density near the cathode surface and reducing the radia? plasma conductivity. Both theoretical and experimental studies of plasma instabilities (refs. 88,89) in self-field MPD thrusters have shown that these phenomena may control the plasma transport properties, indicating that plasma microturbulence has a substantial impact on loss mechanisms within the plasma fluid. These studies have convincingly shown that the same instability mode is dominant in both $30 \mathrm{~kW}$ steady-state and multimegawatt quasi-steady thrusters. Not only will this aid in establishing techniques to control the transport mechanisms, but it also has important implications for the scaling of these devices. Studies of thruster scaling have also been initiated in a cooperative program with Los Alamos National Laboratory, where a large scale plasma gun with an anode diameter of $40 \mathrm{~cm}$ was used to study thruster operation at power levels up to $50 \mathrm{MW}$ (ref. 90). 
MPD thruster lifetime is currently limited by cathode erosion. As discussed in Reference 80, considerable progress has been made over the last 2 to 3 years in identifying the causes of cathode erosion and reducing the magnitude of the mass loss. Conventional rod-shaped cathodes are now being tested which have mass loss rates commensurate with thruster lifetimes of between 300 and $2000 \mathrm{~h}$, depending on the thruster operating condition. In addition, recent results with a high current hollow cathode (ref. 91) indicate that hollow cathodes can be used in MPD thrusters. This technology may provide a way to mitigate the cathode lifetime issue since hollow cathodes have the potential to operate at much lower temperatures than tungsten rod cathodes.

\section{Power Processors}

\section{Arcjet Power Processors}

Arcjet propulsion began in the $1950^{\prime} \mathrm{s}$, and most of the research was conducted for primary propulsion applications at power levels exceeding $10 \mathrm{~kW}$. Laboratory 60 $\mathrm{Hz}$ power supplies with ballast resistors were used to power the engines. Power electronics were not developed because suitable space power systems did not exist at power levels of interest.

During the 1980's the renewed interest in low power hydrazine arcjets led to extensive eforts in power electronics. A lightweight, efficient one-kilowatt prototype power processor was developed in 1986 (refs. 92,93). Of interest was the development of an integral pulse ignition winding on the output current averaging inductor. This circuit generated a high voltage pulse of 3 to $4 \mathrm{kV}$ for about 20 microseconds and was used to breakdown the propellant gas prior to establishing the arc. Power processor conversion efficiency was $91 \%$. The prototype power processor was designed to be electrically isolated from facility or spacecraft ground.

Flight type power electronics were developed based on the breadboard design and were a part of a $1.8 \mathrm{~kW}$ hydrazine arcjet system for NSSK applications (ref. 94). The overall mass was $4.3 \mathrm{~kg}$, and the specific mass was $2.4 \mathrm{~kg} / \mathrm{kW}$. The efficiency of this device was reported to be between $91 \%$ and $94.5 \%$ depending on line and load voltages. The power processor is currently in the final phase of flight qualification.

In anticipation of the increased power capacity of the next-generation satellites, prototype $5 \mathrm{~kW}$ power electronics for hydrazine arcjets were demonstrated in 1989 (ref. 95). This device was successfully integrated to a laboratory $5 \mathrm{~kW}$ hydrazine arcjet. It was found the the starting requirements for $5 \mathrm{~kW}$ arcjets were not significantly different from those of the lower power thrusters. The basic power supply topology was also applied to very low power $(0.4 \mathrm{~kW})$ power electronics for lightsat applications (ref. 96). The efficiency of these power processors was improved to $93 \%$ with the addition of a low inductance power stage layout. All of the prototype power supplies have been successfully integrated with hydrogen arcjets.

In response to the need for a primary propulsion application, $30 \mathrm{~kW}$ power electronics were developed for ammonia arcjets (ref. 97). A three-phase buck regulator topology was selected since isolation was not required for this specific application. This unpackaged power processor has demonstrated a power 
conversion efficiency of about $95 \%$ and a specific mass of $1.8 \mathrm{~kg} / \mathrm{kW}$. The addition of necessary filtering for electromagnetic compatibility, incorporation of space qualified inductors, and packaging for flight will probably increase the specific mass to about $2 \mathrm{~kg} / \mathrm{kW}$. Arcjet starting was accomplished by shorting the output and charging the current averaging inductor. Starts have been demonstrated with ammonia and hydrogen. The lack of input/output isolation allowed higher efficiency and lower specific mass than the previous efforts due to simpler magnetic circuits. However, this device did not have flexibility in grounding schemes due to the lack of gaivanic isolation between input and output stages. For example, on a single point, negative grounded power system, only the arcjet cathode can be grounded. This would result in the arcjet anode going to high potentials when the ignition pulse is applied. Using this configuration, unwanted discharges and conducted/radiated electromagnetic interference could result (ref. 92).

The future applications of hydrogen arcjets will be orbit-raising and other missions requiring primary electric propulsion. At this time $10 \mathrm{~kW}$ power electronics are under development at NASA LeRC (ref. 98). A full-bridge topology was selected based on past experience (ref. 99). Arcjet starting was accomplished with pulse ignition techniques developed for low power thrusters (ref. 93). These power electronics successfully operated up to about $11 \mathrm{~kW}$, and arcjet integration tests have been completed. An efficiency of $94 \%$ was demonstrated; other characteristics are summarized in Table II.

Future work in arcjet power electronics includes development of new magnetics designs and simplified control schemes. Of special interest at higher power levels is the application of coaxial power transformers. A $50 \mathrm{~kW}, 1600 \mathrm{VDC}$ power converter has been developed with a specific mass of $0.2 \mathrm{~kg} / \mathrm{kW}$ and an efficiency of $88 \%$ (ref. 99). Work to improve the power conversion efficiency of this design in an arcjet application is ongoing.

\section{Ion Thruster Power Processors}

Ion thrusters have a long flight history beginning with SERT I and SERT II in the 1960 's (ref. 100). These flights were the first implementation of flight power electronics for a high specific impulse application with mercury propellant. The SERT II power electronics were proved reliable by long ground tests and a space demonstration of many thousands of hours (ref. 50). This power processor made use of the best technology available at the time and employed bipolar switching transistors and magnetic amplifiers for control. The results were a relatively massive power processor with a specific mass of $16.9 \mathrm{~kg} / \mathrm{kW}$ and an efficiency of $87 \%$ at $0.98 \mathrm{~kW}$ input power (refs. 26,51,101). The power processor had a parts count in excess of 1000 .

The ground-based technology demonstration of the Solar Electric Propulsion System (SEPS) resulted in a power processor capable of $3 \mathrm{~kW}$ at an efficiency of $87 \%$ (ref. 58). The specific mass was reduced to $12.3 \mathrm{~kg} / \mathrm{kW}$, but the parts count was about 4000. In the early 1980 's the Ion Auxiliary Propulsion System (IAPS) was conceived as a low power stationkeeping ion thruster subsystem (ref. 102). The $0.17 \mathrm{~kW}$ operational power level hampered the efficiency of the power processor and increased the specific mass to about $66 \mathrm{~kg} / \mathrm{kW}$.

It became obvious that the power processors for ion thruster systems were extremely heavy, inefficient, and complex. Simplification of power processor 
architecture and control schemes began in the late 1970's and early 1980's (ref. 103). Conversion from mercury to inert gas propellants further simplified the power electronics by eliminating the need for propellant.vaporizers and control loops to deal with condensable mercury. The development of high power MOSFET switches reduced the drive requirements for power stages and significantly improved their efficiency. The development of the Xenon Ion Propulsion System (XIPS) by INTELSAT and the Hughes Aircraft Company saw the parts count of the 1.4 $\mathrm{kW}$ power electronics reduced to about 400 (ref. 61), an order of magnitude below devices built for the SEPS program. The efficiency of the power processor was $92 \%$ with a specific mass of $7.9 \mathrm{~kg} / \mathrm{kW}$. This represents a significant improvement over previous models. In addition, a $0.4 \mathrm{~kW}$ version of the XIPS was developed with a power processor specific mass of $13.6 \mathrm{~kg} / \mathrm{kW}$, an efficiency of $88 \%$, and a parts count of about 400 (ref. 63). Table III summarizes the characteristics of power processors developed through the 1980's, and Table IV shows the current power processor parameters.

Other concepts developed in Europe include the ionization of propellant using an RF field, specifically the Radio Frequency Ion Thruster Assembly (RITA) (ref. 104). Power electronics are being developed to interface this thruster to the ARTEMIS satellite. The specific mass was $15.5 \mathrm{~kg} / \mathrm{kW}$ at an input power of $0.6 \mathrm{~kW}$. Overall efficiency data were not available, but the RF generator efficiency was $85 \%$ with a mass of $1.3 \mathrm{~kg}$. At $120 \mathrm{~W}$ dissipation, the RF generator specfic mass was $10.8 \mathrm{~kg} / \mathrm{kW}$. As a precursor to the ARTEMIS flight, an RF ion thruster flight experiment is scheduled for launch in 1992 using the US Shuttle Orbiter and the European Retrievable Carrier (EURECA) (ref. 29). In addition, the UK 10 thruster subsystem, under development in England, incorporated $88 \%$ efficiency power electronics at an input power of $0.75 \mathrm{~kW}$ (ref. 105). The UK I0 propulsion system will also be flown on the ARTEMIS satellite.

An ion thruster system has also been under development in Japan for the ETS VI satellite utilizing two thrusters with a total input power of $1.57 \mathrm{~kW}$ (ref. 106). Power processor efficiency was about $92 \%$.

It appears that the efficiencies of ion thruster power processors were not much improved over efforts in the 1960 to 1980 timeframe. However, the recently developed systems had a much lower power consumption, and the control/telemetry powers were a large fraction of the total power. In general, recently developed power electronics make use of new switching topologies and a higher level of circuit integration to reduce parts count and mass as well as increasing reliability.

\section{EVOLUTIONARY MISSION APPLICATIONS}

High specific impulse electric propulsion has captured the attention of mission planners because low thrust, low specific impulse propulsion accounts for more than $55 \%$ of the spacecraft mass delivered to geocentric orbit and over $70 \%$ of injected planetary spacecraft mass (refs. 2,107). For electric propulsion systems to gain acceptance over conventional chemical systems, the perceived risks encountered by employing the new technology must be overcome, and overall financial or operational benefits must be substantial.

As shown in Table I, hydrazine resistojets have been routinely employed on communication satellites, and the hydrazine arcjet is about to become operational 
on the Telstar 4 communications satellite. Since 1972 the Soviets have flown more than 50 Stationary Plasma Thrusters (SPT) to provide satellite orbit corrections (ref. 4). To date all ion propulsion flights have been experiments, but in 1993 Japan will use ion propulsion for NSSK on the ETS VI (ref. 21). A11 electric thrusters with space qualification heritage have had power levels less than $1 \mathrm{~kW}$ (See Table I and Fig. 1); the Telstar arcjets to be flown in 1993 will operate at about $1.8 \mathrm{~kW}$ (ref. 38). Electric propulsion has been primarily employed as a low power, low thrust system for spacecraft auxiliary propulsion. As the low power electric propulsion technology gains user acceptance, responses to challenging opportunities for high power technology flight demonstrations, orbit transfer applications, and planetary flights can be made after solid technical bridges are made from systems operating at a few kilowatts to higher power systems. The higher power systems will use advanced solar arrays (ref. 8) or nuclear reactor systens, such as the SP-100, which are currently under development (ref.9).

With the exception of Skylab, most United States (US) spacecraft flown to date have had power capabilities of less than $5 \mathrm{~kW}$. Beginning-of-life photovoltaic power capability representative of US spacecraft is shown in Figure 2 . Using such solar power systems or the Advanced Photovoltaic Solar Array (APSA) technology, electric propulsion can perform stationkeeping (refs. 8,38, 106), platform orbit acquisition/orbit maintenance/disposal (refs. 74, 108), primary propulsion for small satellites (ref. 10), and orbit raising excursions into the Van Allen belts (ref. 42). Using arcjets for platform controlled deboost/disposal could be a logical extension of the low power NSSK propulsion technology. For example, the Earth Observing System platform may require more than $1000 \mathrm{~kg}$ of bipropellants for controlled disposal of the platform (ref. 74). The hydrazine arcjet system offers a major saving in propellant and tankage mass because the specific impulse would be increased from about 300 s using bipropellant thrusters to 520 s using hydrazine arcjets. Mass savings could be further increased if low power arcjets were used for platform orbit acquisition, assuming burn times of a month or two are acceptable (ref. 2).

Studies have also indicated that small, low cost spacecraft can be propelled by electric propulsion from low-Earth orbit to geosynchronous orbit or the moon in trip times less than one year using $\mathrm{kW}$-class power systems. One study assumed a nominal spacecraft mass of $225 \mathrm{~kg}$; solar panels were deployed in accordian fashion using extendable booms, and inert gas ion thrusters were used for primary propulsion (ref. 10).

The stationkeeping, platform propulsion, and light-sat applications do not place severe demands on state-of-the-art photovoltaic power systems and batteries. In fact, flight demonstration or operational tests of the arcjet, ion, and pulsed MPD systems are scheduled prior to 1995 (See Table V). Also in 1995 the US Air Force plans to launch the Electric Propulsion Space Experiment (ESEX) in which a $26 \mathrm{~kW}$ ammonia arcjet will demonstrate ten each 15-minute firings and diagnostics will provide information on operational issues such as plume impacts, electromagnetic compatibility, and thermal radiation (ref. 32). In the ESEX experiment power to the propulsion system will be provided by batteries.

Evolution to $10 \mathrm{~kW}$ and higher power electric propulsion systems will require high performance photovoltaic systems of the baseline APSA or modified versions using thin film radiation resistant cells (ref. 8). The technology of lightweight concentrator arrays is now immature; however, if high efficiency cells in a 
radiation shielded package are developed, this concept might be very attractive (ref. 8). Figure 3 shows the parameters of some of the solar array technology demonstrations. In 1971 the $1 \mathrm{~kW}$ Flexible Rollup Sọlar Array (FRUSA) was deployed in a flight test (ref. 109). The FRUSA had a specific power of $45 \mathrm{~W} / \mathrm{kg}$. Later in 1984 the Solar Array Flight Experiment (SAFE) was flight tested aboard the Shuttle Orbiter (ref. 108). The $32 \mathrm{~m}$ fold-out array was successfully deployed. The SAFE array had a $12.5 \mathrm{~kW}$ capability; however, the $1984 \mathrm{flight}$ unit had about $99 \%$ of the area covered with solar cell mass simulators since the main objective of the test was array deployment. The SAFE array had a specific power of $60 \mathrm{~W} / \mathrm{kg}$. At present the Advanced Photovoltaic Solar Array (APSA) is being developed to yield a specific power of $130 \mathrm{~W} / \mathrm{kg}$ for the mast, cannister, and stowage container (ref. 8). An APSA wing is expected to provide $7.8 \mathrm{~kW}$. As stated in Reference 8 , it is like?y near-term SEP missions involving orbit transfer or planetary spacecraft propulsion will use the baseline APSA technology with later versions employing higher performance and more radiation resistant cells as they become available.

The ELITE flight experiment, sponsored by the US Air Force, is a precursor to a solar electric orbit transfer vehicle (SEOTV) flight program (ref. 42). The ELITE, a $10 \mathrm{~kW}$ system, will use arcjets to demonstrate a fully integrated propulsion system as well as demonstrate autonomous guidance, navigation, and control, and spacecraft operations in the Van Allen radiation belts. The Air Force has primary interest in EOTV's operating between low-Earth-orbit and geosynchronous orbit, and thus EOTV power levels will range from about 30 to 100 $\mathrm{kW}$, depending on the results of system trades. Numerous EOTV system studies have been made evaluating the merits of ion and arcjet propulsion systems (refs. $42,110,111)$.

During the 1970's and 1980's there were a significant number of system studies of solar electric propulsion for missions to rendezvous with asteroids and comets (refs. 112,113). Ion propulsion systems and solar array technology were developed to advanced status (refs. 58,108). More recently, the SP-100 space reactor power system has reached a mature level of developinent (ref. 9). A recent study of Nuclear Electric Propulsion (NEP) systems in the $50 \mathrm{~kW}$ to $100 \mathrm{~kW}$ range found NEP enabled the Pluto orbiter mission and provided shorter trip times to Uranus, Neptune, and Pluto (ref. 11). Additionally, the NEP approach provided more frequent launch opportunities. Planetary missions using SEP or NEP must satisfy NASA's core science prograns and show strong benefits over baseline chemical propulsion systems. Confidence in higher power electric propulsion systems will be gained by ground and flight demonstrations of subscale and fullscale systems. The general evolutionary process from low power auxiliary propulsion to primary propulsion using solar and nuclear power systems is shown in Figure 4.

The long-term goal in the electric propulsion evolutionary process is the use of nuclear electric propulsion for cargo and piloted missions to the moon, Mars, and other planets. The evolutionary pathway not only involves propulsion and power technologies but also major advances in power conversion, power management/ distribution, thermal management, and propellant systems. The $10 \mathrm{~kW}$ to $100 \mathrm{~kW}$ class SEP and NEP applications become precursors to NEP cargo and piloted missions to the moon, Mars, and beyond. The Space Exploration Initiative (SEI) is supporting the development of NEP technologies needed for precursor missions, MW-class cargo vehicles, and piloted vehicles requiring about $10 \mathrm{MW}$ to $15 \mathrm{MW}$ (ref. 114). The early focus of the NEP element of the SEI program is the 
evaluation of the feasibility and practicality of NEP system components and the initiation of system studies to determine which subsystems provide the greatest impact on development schedule, mission performance, and cost.

\section{CONCLUDING REMARKS}

Chemical propulsion is a very large fraction of the mass of present communication, orbit raising, and planetary spacecraft. Fuel efficient electric propulsion offers systems which can yield more payload, provide options in launch vehicle selection, accommodate platform boost/deboost functions, and enable a set of planetary missions. Kilowatt-class electric propulsion has found applications for North-South stationkeeping, orbit correction, and spacecraft attitude control. Since most US satellites to date have power capabilities less than 5 kW, near term applications will likely involve stationkeeping, drag makeup, lightsat propulsion, or LEO satellite orbit circularization and deboost functions. As larger solar power capabilities become available, electric propulsion could provide Earth-space propulsion such as orbit raising and spacecraft maneuvering. Higher power SEP and NEP will provide capabilities to support the science related to planets, asteroids, and comets. These experiences will provide firm support for longer range NEP cargo and piloted vehicle excursions to the moon and Mars.

\section{REFERENCES}

1. Curran, F. M., et al., "An Overview of the NASA Electric Propulsion Program," IEPC Paper 91-002, October 1991.

2. Byers, D. C., "Advanced Onboard Propulsion Benefits and Status," NASA TM103174, March 1989.

3. Sovey, J. S., Carney, L. M., and Knowles, S. C., "Electromagnetic Emission Experiences Using Electric Propulsion Systems," Journal of Propulsion and Power, Vol. 5, No. 5, September-October 1989, pp. 534-547.

4. Bober, A. S., et al., "State of Work on Electrical Thrusters in USSR," IEPC Paper 91-003, October 1991.

5. McKevitt, F. X., "Design and Development Approach for the Augmented Catalytic Thruster (ACT)," AIAA Paper 83-1255, June 1983.

6. Dressler, G. A., et al., "Flight Qualification of the Augmented Electrothermal Hydrazine Thruster," AIAA Paper 81-1410, July 1981

7. Feconda, R. T. and Weizman, J. I., "Satellite Reaction Control Subsystems with Auginented Catalytic Thrusters," AIAA Paper 84-1235, July 1984.

8. Stella, P., "Photovoltaic Options for Solar Electric Propulsion," AIAA Paper 90-2529, July 1990.

9. Mondt, J., "Overview of the SP-100 Program," AIAA Paper 91-3585, September 1991. 
10. Meissinger, H. F., "A Smal1, Primary Solar-Electric Propulsion Demonstration Satellite," Proceedings of the 5th Annual AIAA/Utah State University Conference on Small Satellites, August 1991.

11. Yen, C. L. and Sauer, C. G., "Nuclear Electric Propulsion for Future NASA Space Science Missions," IEPC Paper 91-035, October 1991.

12. Guman, W. J. and Nathanson, D. M., "Pulsed Plasma Microthruster Propulsion System for Synchronous Orbit Satellite," Journal of Spacecraft and Rockets, Vol. 7, March-April 1970, pp. 409-415.

13. Guman, W. J. and Kowal, S. J., "Pulsed Plasma Propulsion System for the TIP-II Satellite," 1975 JANNAF Propulsion Conference, Vol. 1., edited by T. M. Gilliland, Chemical Propulsion Information Agency, Laurel, MD, CPIAPUBL-266-VOL-1, 1975, pp. 443-458.

14. Hirata, M. and Murakami, H., "Electromagnetic Noise Measurement Study of Pulsed Plasma Engine," AIAA Paper 81-0722, April 1981.

15. An, S., et al., "Space Flight Test of MDT-2A," AIAA Paper 82-1874, November 1982 .

16. Brill, Y., Eisner, A., and Osborn, L., "The Flight Application of a Pulsed Plasma Microthruster: The NOVA Satellite," AIAA Paper 82-1956, November 1982.

17. Ebert, W. L., Kowal, S. J., and Sloan, R. F., "Operational NOVA Spacecraft Teflon Pulsed Plasma Thruster System," AIAA Paper 89-2497, July 1989.

18. Zhurin, V. V., Porotnikov, A. A., and Borisova, S. B., "Recent Developments in Electric Propulsion in the USSR," AIAA Paper 83-1397, June 1983.

19. Kuriki, K., Nakamaru, K., and Morimoto, S., "MPD Thruster Test on Engineering Test Satellite," AIAA Paper 79-2071, October 1979.

20. Kuriki, K., et al., "Space Experiment with Particle Accelerators (SEPAC) Performed on Spacelab First," AIAA Paper 85-1996, September 1985.

21. Yoshikawa, T., "Electric Propulsion Research and Development in Japan," IEPC Paper 91-004, October 1991.

22. Cybulski, R. J., et al., "Results from SERT I Ion Rocket Flight Test," NASA TN D-2718, 1965.

23. Sellen, J.M., Jr., "Interaction of Spacecraft Science and Engineering Subsystems with Electric Propulsion Systems," AIAA Paper 69-1106, October 1969 .

24. Lazar, J., "Review of the NASA Program in Electric Propulsion," AIAA Paper 69-248, March 1969.

25. 01sen, R. C., "Experiments in Charge Control at Geosynchronous Orbit-ATS-5 and ATS $-6, "$ Journal of Spacecraft and Rockets, Vol. 22, May- June 1985, pp. 254-264. 
26. Kerslake, W. R., "SERT II Thrusters - Still Ticking After Eleven Years," AIAA Paper 81-1539, July 1981.

27. Worlock, R. M., et al., "The Cesium Bombardment Engine North-South Stationkeeping Experiment on ATS-6," AIAA Paper 75-363, March 1975.

28. Kitamura, S., "Development of the Engineering Test Satellite-III (ETS-III) Ion Engine System," NASA TM-77538, 1984.

29. Bartoli, C., "Review of European Activities on Electric Propulsion," IEPC Paper 91-001, October 1991.

30. Masek, T. D. and Cohen, H. A., "Satellite Positive-Ion-Beam System," Journal of Spacecraft and Rockets, Vol. 15, January-February 1978, pp. $2 \overline{7-33}$.

31. Mirtich, M. J., "Resistojet Propulsion for Large Spacecraft Systems," AIAA Paper 82-1948, November 1982. (a1so NASA TM-83489.)

32. Sanks, T. M., Raygor, B. L., and Birkan, M. A., "The Status and Future Plans for Electric Propulsion Development by the United States Air Force," IEPC Paper 91-006, October 1991.

33. Jackson, F. A., et al., "An Operational Electrothermal Propulsion System for Spacecraft Reaction Control," AIAA Paper 66-213, March 1966.

34. Heckert, B. J., "Space Station Resistojet System Requirements and Interface Definition Study," NASA CR-179581, February 1987.

35. Morren, W. E., et al., "Performance Characterizations of an Engineering Model Resistojet," Journal of Propulsion and Power, Vol. 5, No. 2, MarchApril 1989, pp. 197-203.

36. Slutz, R. J., "A 10,000. Hour Lifetest of an Engineering Model Resistojet," NASA TM-103216, October 1990.

37. Morren, W. E. and Stone, J. R., "Development of a Liquid Fed Water Resistojet," AIAA Paper 88-3288, JuTy 1988.

38. Smith, W. W., et al., "Low Power Hydrazine Arcjet Flight Qualification," IEPC Paper 91-148, October 1991.

39. Zafran, S., "Arcjet System Integration Development Program," NASA CR$187147,1992$.

40. Miller, L., "The $\mathrm{Ni}-\mathrm{H}_{2}$ Battery System: A Space Flight Application Summary," Proceedings of the 23rd Intersociety Energy Conversion Engineering Conference, July 1988, pp. 489-492.

41. Pivirotto, T. J. and Deininger, W. D., "Electrode Erosion in Steady-State Electric Propulsion Engines," IEPC Paper 88-074, October 1988.

42. DeVincenzi, D. L, , et al., "ELITE Systems Analysis," AIAA Paper 90-2530, July 1990. 
43. Polk, J. E. and Goodfellow, K. D., "Endurance Test of an Ammonia Arcjet at 10 kWe," IEPC Paper 91-068, October 1991.

44. Golz, T. M., et al., "High Power Arcjet Thruster Experiments," IEPC Paper 91-072, October 1991.

45. Haag, T. W. and Curran, F。 M., "High Power Hydrogen Arcjet Performance," AIAA Paper 91-2227, June 1991.

46. Piszcor, M. F., Swartz, C. K., and 0'Nei11, M. J., "Component and Prototype Testing of the Minidome Fresnel Lens Photovoltaic Concentrator Array," Proceedings of the 25th IECEC, Vol. 1, 1990, pp. 598-603.

47. Kaufman, H. R., "An Ion Rocket with an Electron-Bombardment Ion Source," NASA TN D-585, 1961.

48. Korovkin, V. N., et al., "Research of Ion Thrusters in the USSR," IEPC Paper 91-081, October 1991.

49. Goldman, R. G., Gurski, G. S., and Hawersaat, W. H., "Description of the SERT II Spacecraft and Mission," NASA TMX-52862, 1970.

50. Kerslake, W. R., Goldman, R. G., and Nieberding, W. C., "SERT II-Mission, Thruster Performance and In-Flight Thrust Measurements," Journal of Spacecraft and Rockets, Vol. 8, No. 3, March 1971, pp. 213-224.

51. Rulis, R. J., "SERT-II: Design Requirements for Integrating Electric Propulsion into a Spacecraft," Journal of Spacecraft and Rockets, Vol. 8, March-April 1971, pp. 209-213.

52. Kitamura, S., et al., "Review of Engineering Test Satellite III Ion Engine Project," IEPC Paper 84-17, May 1984.

53. Kitamura, S., et al, "ETS-III Ion Engine Flight Operations in the Extended Mission Period," Journal of Propulsion and Power, Vol. 2, No. 6, 1986.

54. Dulgeroff, C. R., et al., "Ion Thruster System $(8 \mathrm{~cm})$ Cyclic Endurance Test," NASA CR 174745, October 1984.

55. Power, J. L., "Ground Correlation Investigation of Thruster/Spacecraft Interactions to be Measured on the IAPS Flight Test," IEPC Paper 84-39, May 1984 (also NASA TM 83598.)

56. Francisco, D. R., Low, C. A., Jr., and Power, J. L., "Successful Completion of a Cylic Ground Test of a Mercury Ion Auxiliary Propulsion System," IEPC Paper 88-35, October 1988.

57. Anon., "A Case History of Technology Transfer," NASA TM 82618, 1981.

58. Anon., "30-Centimeter Ion Thrust Subsystem Design Manual," NASA TM $79191,1979$.

59. Rawlin, V. K., "Operation of the J-Series Thruster Using Inert Gas," AIAA Paper 82-1929, November 1982. 
60. Aston, G., et al., "Operating Characteristics of a 10-kW Ion Propulsion Module," AIAA Paper 87-1006, May 1987.

61. Beattie, J. R., et al., "Xenon Ion Propulsion System," AIAA Paper 852012, September 1985.--

62. Beattie, J. R., Matossian, J. N., and Robson, R. R., "Status of Xenon Ion Propulsion Technology," AIAA Paper 87-1003, May 1987.

63. Beattie, J. R., Robson, R. R., and Williams, J. D., "18-mN Xenon Ion Propulsion Subsystem," IEPC Paper 91-010, October 1991.

64. Shimada, S., et al., "20-mN Class Xenon Ion Thruster for ETS-VI," AIAA Paper 87-1029, May 1987.

65. Kuriki, K. and Nakamura, Y., "Electric Propulsion Projects and Researchers in Japan," IEPC Paper 88-003, October 1988.

66. Bassner, H., et al., "Recent Developments of the North-South Stationkeeping Engines of the RIT-Family," IAF Paper 89-273, 1989.

67. Bassner, H., Berg, H., and Kukies, R., "The Design of RITA Electric Propulsion System for SAT 2 (ARTEMIS)," IEPC Paper 90-2539, July 1990.

68. Bassner, H., Bartoli, C., and Trippi, A., "Status of the RITA-Experiment of EURECA," IEPC Paper 88-029, 0ctober 1988.

69. Protto, M., et a1., "System Programmatic Aspects of the Ion Propulsion Package Aboard the Artemis Satellite," IEPC Paper 91-144, October 1991.

70. Watson, S. D., "The UK-10 Ion Thruster Test Programme at AEA Technology, Culham Laboratory," IEPC Paper 91-056, October 1991.

71. Hack, K. J., et al., "Evolutionary Use of Nuclear Electric Propulsion," AIAA Paper 90-3821, September 1990.

72. Patterson, M. J. and Verhey, T. R., "5-kW Xenon Ion Thruster Lifetest," AIAA Paper 90-2543, July 1990.

73. Rawlin, V. K. and Majcher, G. A., "Mass Comparisons of Electric Propulsion Systems for NSSK of Geosynchronous Spacecraft," AIAA Paper 91-2347, June 1991.

74. Sovey, J. S. and Pidgeon, D. J., "Advanced Propulsion for LEO and GEO Platforms," AIAA Paper 90-2551, July 1990.

75. Deininger, W. D. and Vondra, R. J., "Electric Propulsion for Constellation Deployment and Space Maneuvering," AIAA Paper 88-2833, July 1988.

76. Patterson, M. J. and Foster, J. E., "Performance and Characterization of a "Derated" Ion Thruster for Auxiliary Propulsion," AIAA Paper 91-2350, June 1991. 
77. Patterson, M. J. and Rawl in, V. K., "Derated Ion Thruster Design Issues," IEPC Paper 91-150, October 1991.

78. Rawlin, V. K., "Advanced Ion Propulsion for Space Exploration," AIAA Paper 91-3567, September 1991.

79. Bugrova, A. I., et al., "Physical Processes and Characteristics of Stationary Plasma Thrusters with Closed Electron Drift," IEPC Paper 91-079, October 1991.

80. Myers, R. M., Mantenieks, M. A., and LaPointe, M. R., "MPD Thruster Technology," AIAA Paper 91-3568, September 1991.

81. Sovey, J. S. and Mantenieks, M. A., "Performance and Lifetime Assessment of MPD Arc Thruster Technology," Journal of Propulsion and Power, Vol. 7 , No. 1, January-February 1991, pp. 71-83.

82. Myers, R. M., "Applied-Field MPD Thruster Geometry Effects," AIAA Paper 91-2342, June 1991 (also NASA CR 187163.)

83. Gallimore, A. D., et al., "Anode Power Deposition in an Applied-Field Segmented-Anode MPD Thruster," AIAA Paper 91-2343, June 1991.

84. Myers, R. M., Mantenieks, M. A., and Sovey, J. S., "Geometric Effects in Applied-Field MPD Thrusters," AIAA Paper 90-2669, July 1990. (also NASA TM 103259:)

85. Gallimore, A. D., Kelly, A. J., and Jahn, R. G., "Anode Power Deposition in MPD Thrusters," IEPC Paper 91-125, October 1991.

86. Myers, R. M., et al., "A Preliminary Characterization of Applied-Field MPD Thruster Plumes," AIAA Paper 91-2339, June 1991. (also NASA CR 187165.)

87. York, T. M., Zakrzwski, C., and Soulas, G., "Diagnostics and Performance of a 1/4 Scale MPD Thruster," AIAA Paper 90-2665, July 1990.

88. Choueiri, E., Kelly, A. J., and Jahn, R. G., "Current-Driven Plasma Acceleration Versus Current-Driven Energy Dissipation. Part 1: Wave Stability Theory," AIAA Paper 90-2610, July 1990.

89. Tilley, D. L., "An Investigation of Microinstabilities in a kW Level SelfField MPD Thruster," M.S.E. Thesis 1917-T, Mechanical and Aerospace Engineering Department, Princeton University, NJ, 09544, October 1991.

90. Schoenberg, K., et al. "Coaxial Plasma Thrusters for High Specific Impulse Propulsion," AIAA Paper 91-3570, September 1991.

91. Mantenieks, M. A. and Myers, R. M., "Preliminary Results of a Hollow Cathode Cathode MPD Thruster," IEPC Paper 91-076, October 1991.

92. Gruber, R. P., "Power Electronics for a 1-kilowatt Arcjet Thruster," AIAA Paper 86-1507, June 1986. (also NASA TM 87340.) 
93. Sarmiento, C. J. and Gruber, R. P., "Low Power Arcjet Pulse Ignition," AIAA Paper 87-1951, July 1987. (also NASA TM 100123.)

94. Smith, R. D., et al., "Development and Demonstration of a $1.8 \mathrm{~kW}$ Hydrazine Arcjet Thruster," AIAA Paper 90-2547, July 1990.

95. Gruber, R. P., Gott, R. W., and Haag, T. W., "5-kW Arcjet Power Electronics," AIAA Paper 89-2725, JuTy 1989. (also NASA TM 102108.)

96. Hamley, J. A. and Hil1, G. M., "Power Electronics for Low Power Arcjets," AlAA Paper 91-1991, June 1991. (also NASA TM 104459.)

97. Wong, S., et al., "Operational Testing of the Power Conditioning Unit for a 30-kwe Arcjet,". Proceedings of the Eighth Symposium on Space Nuclear, Power Systems, January 1991, pp. 982-987.

98. Hamley, J. A., Pinero, L. R., and Hill, G. M., "10-kW Power Electronics for Hydrogen Arcjets," 1992 JANNAF Propulsion Conference, Chemical Propulsion Information Agency, February, 1992.

99. Divan, D. J. and Kheraluwala, M. H., "High Power Density DC-DC Converters for Aerospace Applications," NAG3-804 Final Report, 1991.

100. Rawlin, V. K., Patterson, M. J., and Gruber, R. P., "Xenon Ion Propulsion for Orbit Transfer," AIAA Paper 90-2527, July 1990. (also NASA TM 103193.)

101. Bagwe11, J. W., "Review of SERT II Power Conditioning," Journal of Spacecraft and Rockets, Vol. 8, No. 3, March 1971, pp. 225-230.

102. Wessel, F. J., et al., "8-cm Ion Thruster Characterization," NASA CR 180819, October 1987.

103. Rawl in, V. K., "Reduced Power Processor Requirements for the $30 \mathrm{~cm}$ Diameter Hg Ion Thruster," AIAA Paper 79-2081, October 1979.

104. Bassner, H., Berg, H. P., and Kukies, R., "RITA Development and Fabrication of the ARTEMIS Satellite," IEPC Paper 91-057, October 1991.

105. Love11, M., "The UK-10 Power Conditioning and Control Equipment," AIAA Paper 90-2631, July 1990.

106. Shimada, S., et a1., "Ion Engine System Development of ETS VI,' IEPC 91 145, October 1991.

107. Stone, J. R. and Bennett, G. L., "The NASA Low Thrust Propulsion Program," AIAA Paper 89-2492, July 1989.

108. Elms, R. V., Hill, H. C., and Young, L. E., "Solar Array Shuttle Flight Experiment - Hardware Developinent and Testing," Proceedings of the Sixteenth IEEE Photovoltaics Specialists Conference, September 1982, pp. 25-30. 
109. Wolff, G., "The Flight of the FRUSA," Proceedings of the IEEE Photovoltaics Specialists Conference, 1972.

110. Hermel, J., et al., "Modular, Ion-Propelled Orbit Transfer Vehicle," Journal of Spacecraft and Rockets, Vol. 25, No. 5, September-October 1988, pp. 368-374.

111. Miller T. M., "Systems Analysis for an Operational EOTV," IEPC Paper 91-133, Gctober 1991.

112. Duxbury, J. H., "Solar Electric Spacecraft for the Encke Slow Flyby Mission," AIAA Paper 73-1126, November 1973.

113. Gilbert, J. and Guttman, C. H., "Evolution of the Common SEP Stage (COMSEPS)," AIAA Paper 73-1122, 1973.

114. Stone, J. R., "Nuclear Electric Propulsion: An Integral Part of NASA's Nuclear Propulsion Project," Proceedings of the 9th Symposium on Space Nuclear Power Systems," January 1992, pp. 1177-1182. 

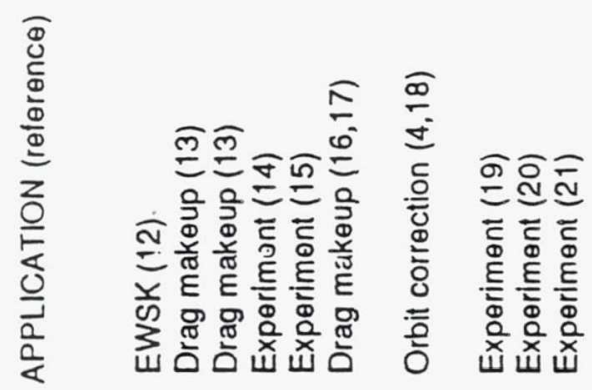

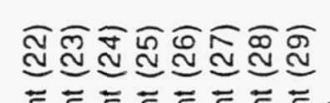

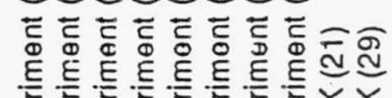

등 등 등 등 등 돟



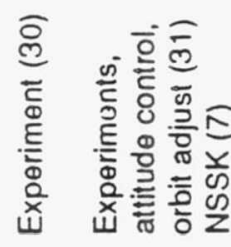

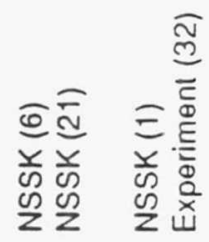

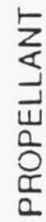

듷등등드음

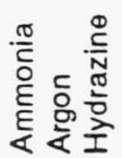

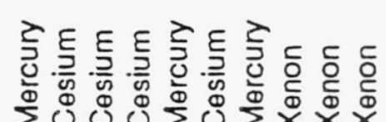

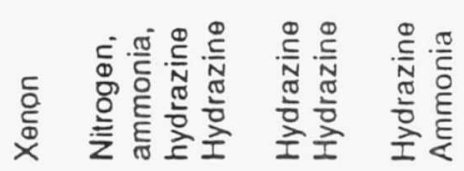

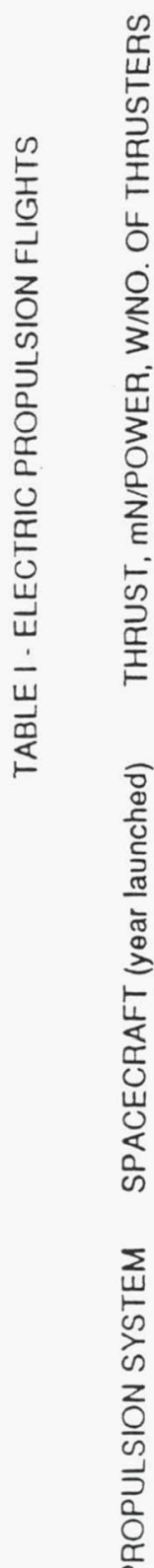

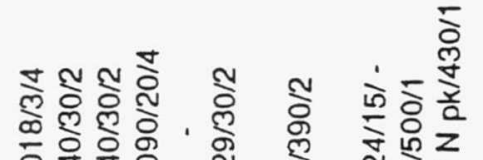

웅융유

ลัก

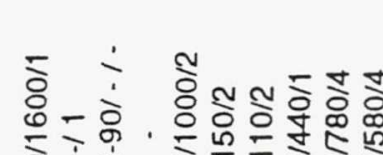

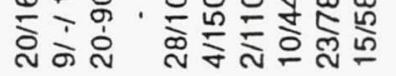

$\begin{array}{cc} & \dot{1} \\ \overline{0} & 0 \\ 0 & 0 \\ 0 & 0 \\ \text { ते } & 0 \\ 0 & 0 \\ 0 & 0\end{array}$

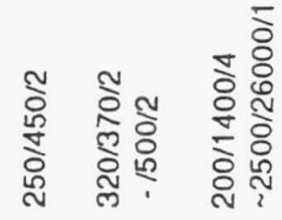

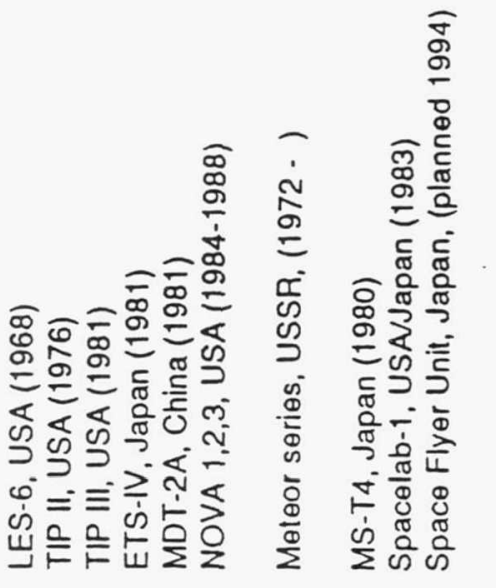

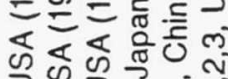

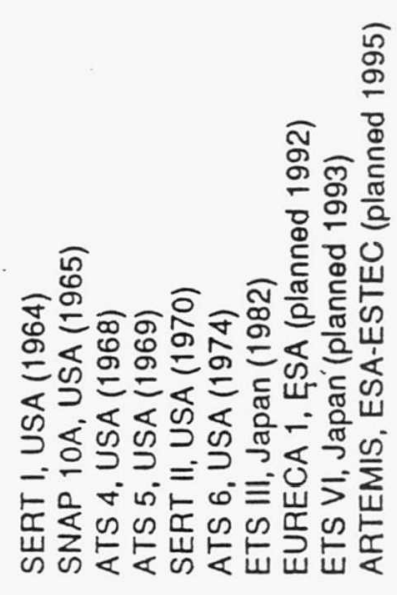

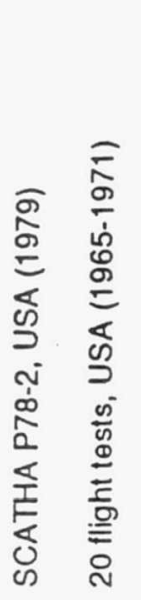

崖

$\varphi^{\circ} \equiv \geq$

出高高哣完

टके

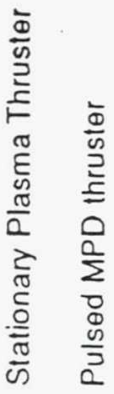

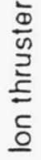

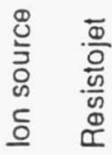


Table II. Power electronics for arcjet subsystems

\begin{tabular}{|c|c|c|c|c|c|c|}
\hline Propellant & Hydrazine & Hydrazire & $\begin{array}{c}\text { Hydrazirie/ } \\
\text { Hydrogen }\end{array}$ & Ammonia & Hydrazine & Hydrogen \\
\hline Type & Breadboard & Flight & Breadboard & Breadboard & Breadboard & Breadboard \\
\hline $\begin{array}{l}\text { Power } \\
\text { Level, kW }\end{array}$ & 1 & 1.8 & 5 & 30 & 0.4 & 10 \\
\hline $\begin{array}{l}\text { Efficiency, } \\
\%\end{array}$ & 91 & $>90$ & 93 & 95 & 93 & 94 \\
\hline $\begin{array}{l}\text { Specific } \\
\text { Mass, } \\
\text { kg/kW }\end{array}$ & $\mathrm{N} / \mathrm{A}$ & 2.4 & $N / A$ & 1.8 & $N / A$ & $N / A$ \\
\hline Topology & $\begin{array}{c}\text { Isolated } \\
\text { (Push-Pull) }\end{array}$ & Isolated & $\begin{array}{l}\text { Isolated } \\
\text { (Bridge) }\end{array}$ & $\begin{array}{c}\text { Non-isolated } \\
\text { ( } 3 \text { phase } \\
\text { buck) }\end{array}$ & $\begin{array}{l}\text { Isolated } \\
\text { (Bridge) }\end{array}$ & $\begin{array}{l}\text { Isolated } \\
\text { (Bridge) }\end{array}$ \\
\hline Reference & 92 & 94 & 95 & 97 & 96 & 98 \\
\hline
\end{tabular}


Table III. Historical summary of power electronics developed for ion propulsion subsystems

\begin{tabular}{|l|c|c|c|c|}
\hline $\begin{array}{l}\text { Power } \\
\text { Processor }\end{array}$ & SERT II & SEPS & IAPS & XIPS \\
Propellant & Mercury & Mercury & Mercury & Xenon \\
$\begin{array}{l}\text { Input Power } \\
\text { Level, kW }\end{array}$ & 0.98 & 3.05 & 0.17 & 1.4 \\
$\begin{array}{l}\text { Power } \\
\text { Efficiency,\% }\end{array}$ & 87 & 87 & 75 & 92 \\
$\begin{array}{l}\text { Specific Mass, } \\
\text { kg/kW }\end{array}$ & 16.9 & 12.3 & 66 & 7.9 \\
$\begin{array}{l}\text { Approximate } \\
\text { Parts Count }\end{array}$ & 1100 & 4000 & 1700 & 400 \\
Reference & 101 & 58 & 54 & 61 \\
\hline
\end{tabular}


Table IV. Current power electronics development for ion propuision subsystems

\begin{tabular}{|c|c|c|c|c|}
\hline $\begin{array}{l}\text { Power } \\
\text { Processor }\end{array}$ & RITA (Germany) & UK-10 (U.K.) & ETS-VI (Japan) & XIPS (U.S.A.) \\
\hline $\begin{array}{l}\text { Input Power } \\
\text { Level, } \\
k W\end{array}$ & 0.58 & 0.75 & 0.79 & 0.44 \\
\hline $\begin{array}{l}\text { Specific Mass, } \\
\mathrm{kg} / \mathrm{kW}\end{array}$ & $\begin{array}{c}15.5^{\circ} \\
\text { (Calculated) }\end{array}$ & $N / A$ & $N / A$ & 13.6 \\
\hline $\begin{array}{l}\text { Power } \\
\text { Efficiency }\end{array}$ & 0.85 (RF only) & 0.88 & $\begin{array}{c}0.92^{\circ} \\
\text { (Calculated) }\end{array}$ & 0.88 \\
\hline Reference & 104 & 105 & 106 & 63 \\
\hline
\end{tabular}




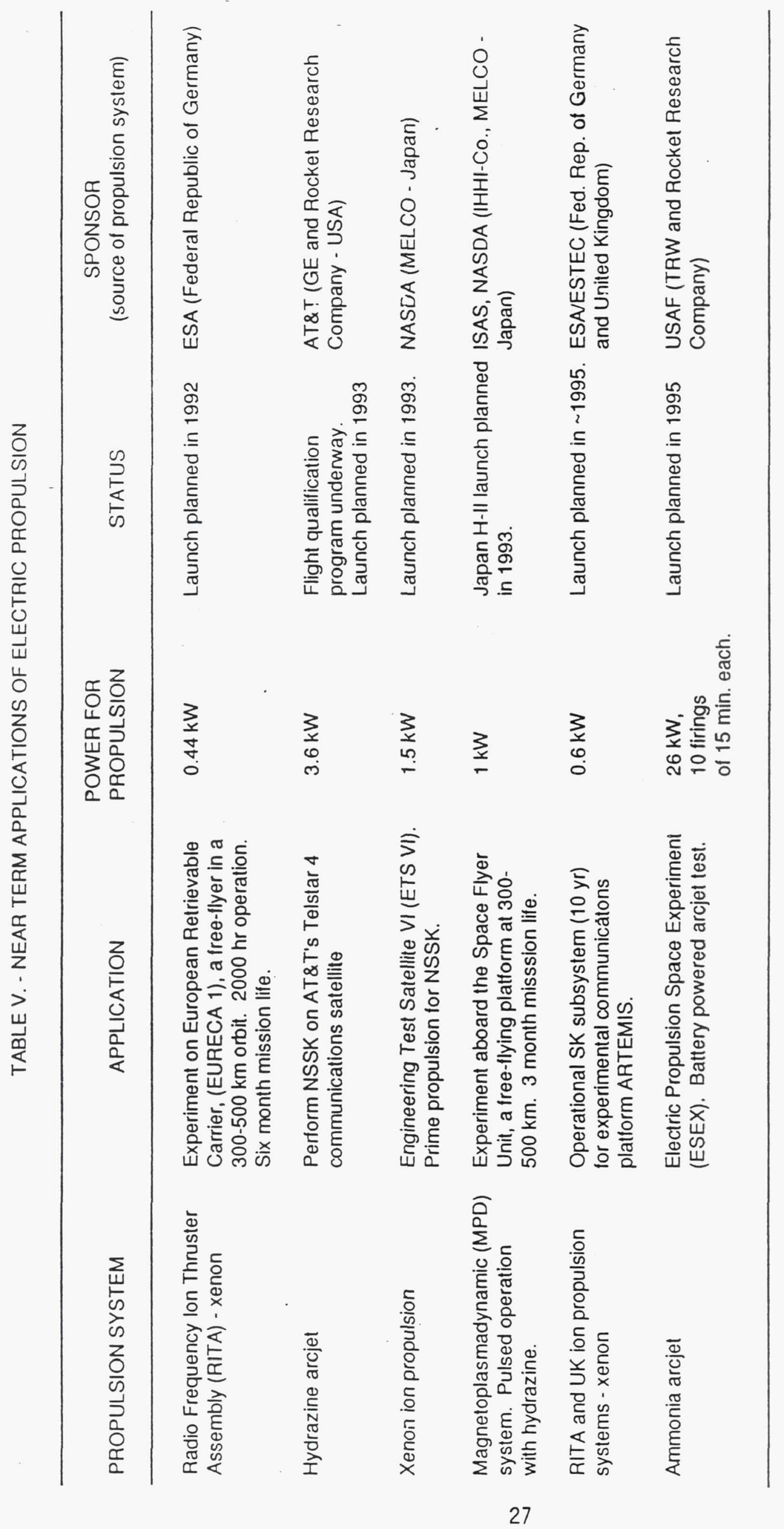




\section{THRUSTER POWER, $\mathrm{kW}$}
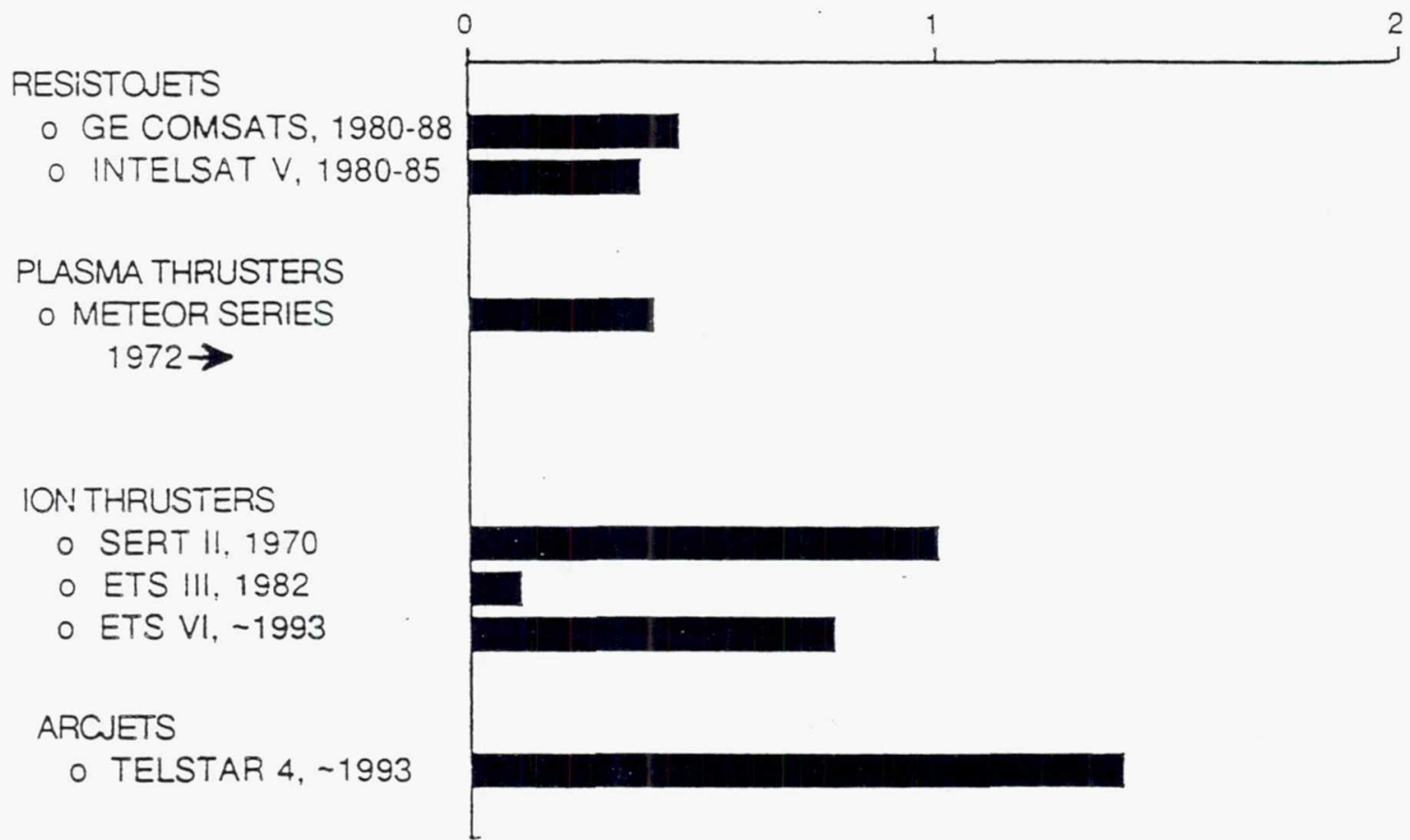

Figure 1. - Power levels of representative electric thrusters flown since 1970 
SPACECRAFT POWER, $\mathrm{kW}$

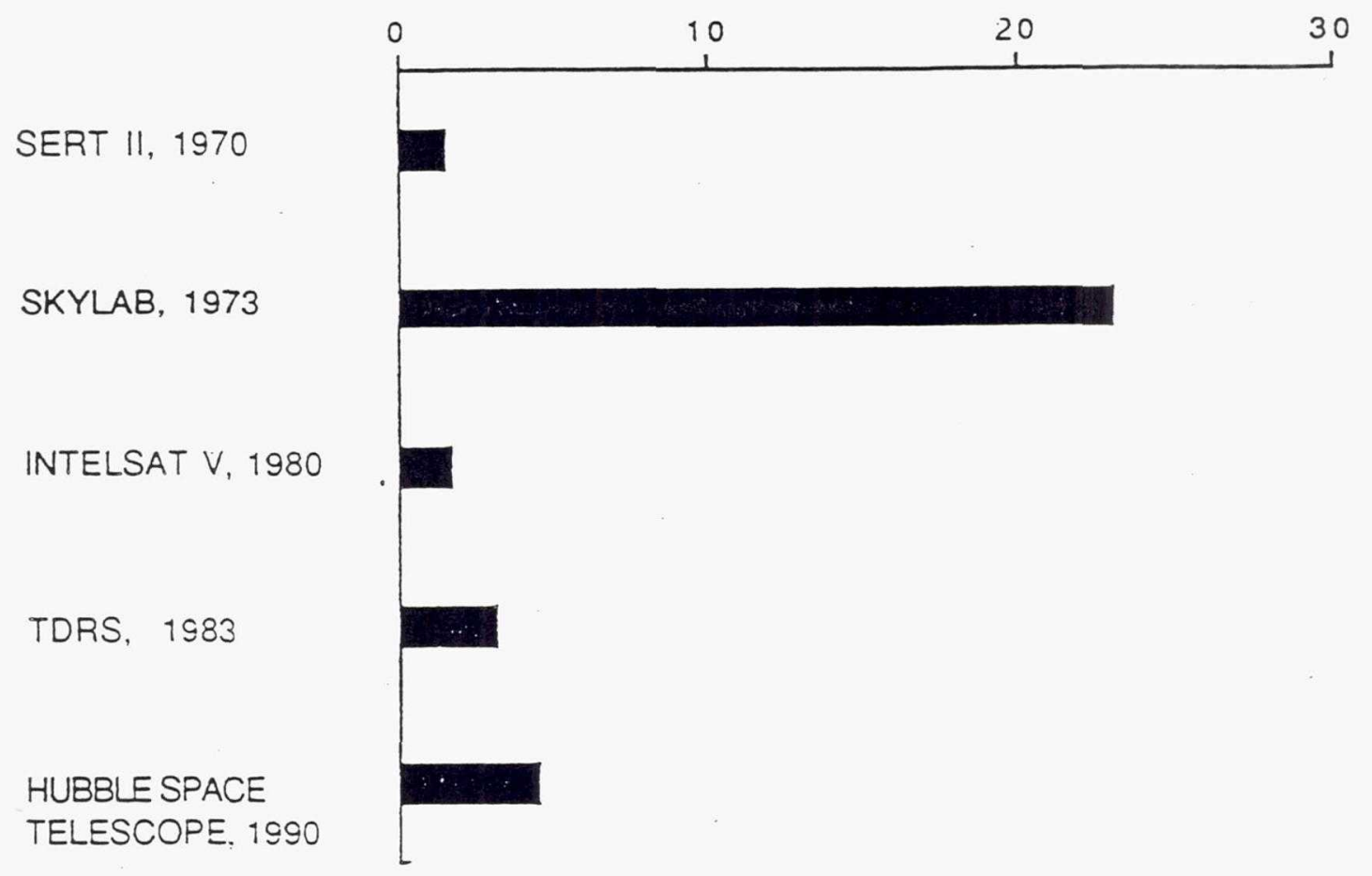

Figure 2. - Solar power capability of representative spacecraft. 


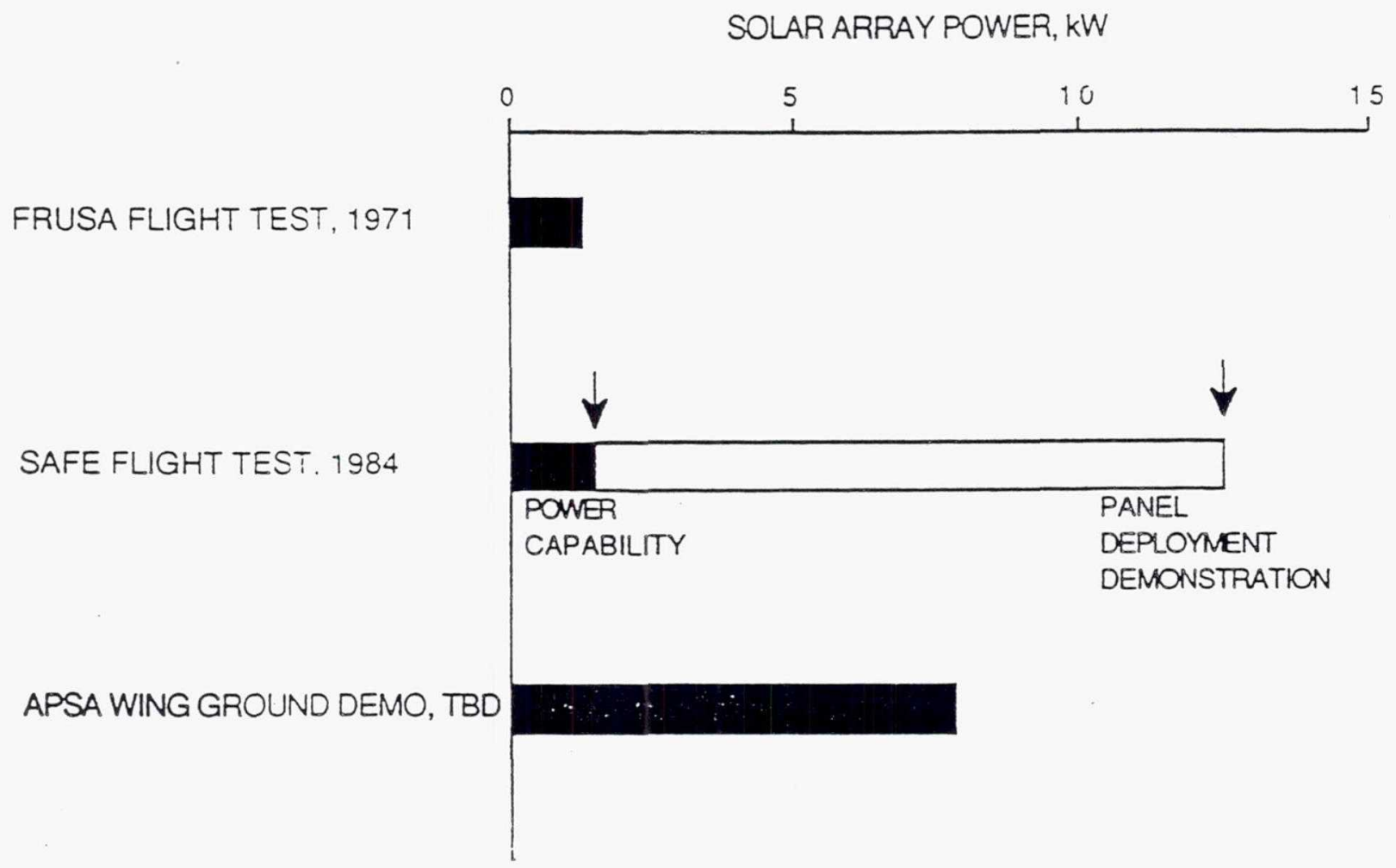

Figure 3. - Characteristics of solar array technology demonstrations. 


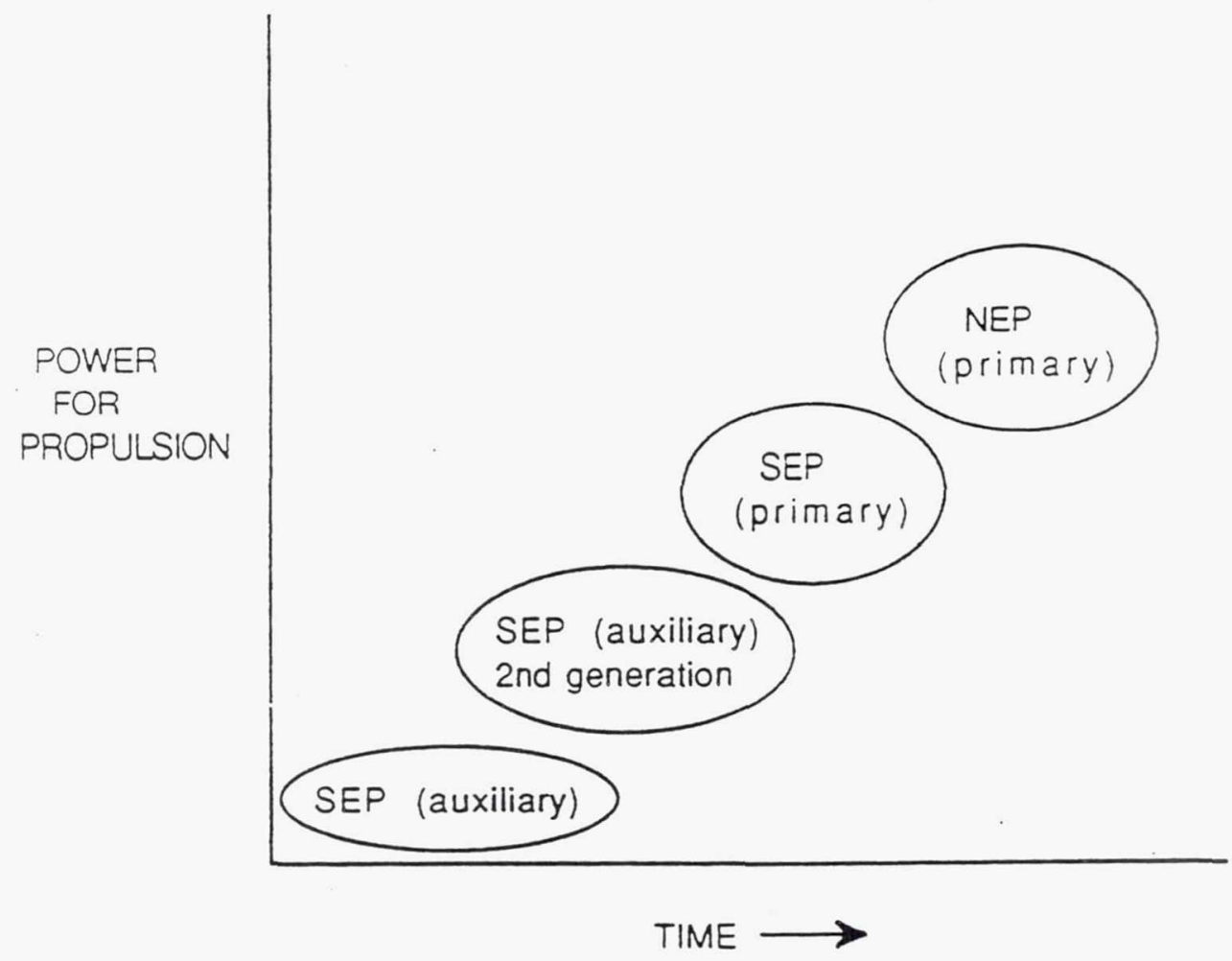

Figure 4. - Evolution of e!ectric propulsion. 


\section{REPORT DOCUMENTATION PAGE}

Public reporting burden for this collection of information is estimated to average 1 thour per response, including the time for reviewing instructions. searching existing data sources, gathering and maintaining the data needed. and completing and reviemng the collection of information. Send comments regarding this burden estumate or any other aspect of this collection of information, including suggestions for reducing this burden, to Washngton Headquariers Services, Directorate for information Operations and Reports, 1215 Jefferson Davis Highway, Surte 1204. Arlington, VA 22202-4302, and to the Otfice of Management and Budget. Papenwork Reduction Project (0704-0188), Washington, DC 20503.

\begin{tabular}{|l|c|r|r|}
\hline 1. AGENCY USE ONLY (Leave blank) & $\begin{array}{r}\text { 2. REPORT DATE } \\
\text { March } 1992\end{array}$ & $\begin{array}{r}\text { 3. REPORT TYPE AND DATES COVERED } \\
\text { Technical Memorandum }\end{array}$ \\
\hline
\end{tabular}

4. TITLE AND SUBTITLE

5. FUNDING NUMBERS

The Evolutionary Development of High Specific Impulse Electric

Thruster Technology

6. AUTHOR(S)

WU-506-42-31

James S. Sovey, John A. Hamley, Michael J. Patterson, Vincent K. Rawlin, and Roger M. Meyers

7. PERFORMING ORGANIZATION NAME(S) AND ADDRESS(ES)

8. PERFORMING ORGANIZATION REPORT NUMBER

National Aeronautics and Space Administration

Lewis Research Center

Cleveland, Ohio 44135-3191

$\mathrm{E}-7170$

9. SPONSORING/MONITORING AGENCY NAMES(S) AND ADDRESS(ES)

10. SPONSORING/MONITORING AGENCY REPORT NUMBER

National Aeronautics and Space Administration

Washington, D.C. 20546-0001

NASA TM-105758

11. SUPPLEMENTARY NOTES

Prepared for the Space Programs and Technologies Conference sponsored by the American Institute of Aeronautics and Astronautics.

12a. DISTRIBUTION/AVAILABILITY STATEMENT

12b. DISTRIBUTION CODE

Unclassified - Unlimited

Subject Category 20

13. ABSTRACT (Maximum 200 words)

Electric propulsion flight and technology demonstrations conducted primarily by Europe, Japan, Peoples Republic of China, USA, and USSR are reviewed. Evolutionary mission applications for high specific impulse electric thruster systems are discussed, and the status of arcjet, ion, and magnetoplasmadynamic thruster and associated power processor technologies are summarized.

14. SUBJECT TERMS

Electric propulsion; Space propulsion; Electric thrusters; Plasma applications

5. NUMBER OF PAGES 32

16. PRICE CODE

$\mathrm{AO3}$

17. SECURITY CLASSIFICATION OF REPORT

Unclassified
18. SECURITY CLASSIFICATION OF THIS PAGE Unclassified
19. SECURTY CLASSIFICATION OF ABSTRACT Unclassified 